\title{
Molecular Characterization of an Unidentified Cichlid, Commonlly Called, 'Wesafu', Using Rapd Markers
}

\author{
Megbowon $\mathrm{I}^{1}$ and Fashina-Bombata, H. $\mathrm{A}^{2}$ \\ ${ }^{1}$ Aquaculture Dept., Nigerian Institute for Oceanography and Marine Research, Victoria Island, Lagos \\ ${ }^{2}$ Faculty of science, Lagos State University, Ojo, Lagos
}

\begin{abstract}
Abstarct: Genetic variation and divergence within and between the taxa of interest are assessed by the presence or absence of each product, which is dictated by changes in the DNA sequence at each locus. The study was conducted to assess the genetic differences between population of 'wesafu' and other cichlids in Epe legoon, Lagos, Nigeria and determine the level of divergence of 'wesafu' from other species of cichlids in Epe lagoon for baseline documentation. The genomic DNA was isolated using the standard phenol - chloroform method. Primer OPC-04 (5' CCG CAT CTA C 3'), which are arbitrary primers, were used to type the isolates. The results showed that of the 40 fish isolates typed, 29 isolates (17 of 'Wesafu' and 12 of other cichlids) were positive for RAPD DNA bands after amplification. This gives a type ability of $72.5 \%$. The difference observed between 'Wesafu' and other cichlids in typeability with OPC-04 was not significant $(P=0.08)$. Fingerprint analyses revealed 6 distinct RAPD types, 3 for 'wesafu' and 3 for other species of cichlids with molecular sizes of 100 - 500 base pairs. RAPD profile B was elicited by $58.3 \%$ of the Tilapia (other cichlids) isolates, while profile $F$ was elicited by 53\% of the 'Wesafu' isolates. These most occurring RAPD profiles were not significant $(P>0.05)$ when compared with other RAPD profiles seen. RAPD-PCR proves to be reliable as a typing tool for discriminating 'Wesafu' from other cichlids (tilapia) isolates in Epe Lagoon. 'Wesafu' and other (cichlids) tilapia in the Epe Lagoon present fish population from 3 distinct clones.
\end{abstract}

Key words: Molecular, Characterization, 'wesafu', RAPD

\section{Introduction}

Recent advances in molecular biology have provided the basis for uncovering unlimited numbers of DNA markers. RAPD technique is simple and applicable and in a number of fish species and this has captivated the interest of many scientists. The main reason for the success of RAPD analysis is most probably because of the gain of a large number of genetic markers that require small amounts of DNA without the requirement for cloning, sequencing or any other form of the molecular characterization of the genome of the species under investigation.

Genetic variation and divergence within and between the taxonomic groups of interest are usually assessed by the presence or absence of each product, which is influenced by changes in the DNA sequence at each locus. RAPD polymorphisms can occur as a result of base substitutions at the primer binding sites or to indels in the regions between the sites. The potential power is relatively high for detection of polymorphism; typically, 5-20 bands can be produced using a given primer pair, and multiple sets of random primers can be used to scan the entire genome for differential RAPD bands.

RAPDs have all the merit of a PCR-based marker, with the added advantage that primers are commercially available and do not require previous knowledge of the target DNA sequence. Multilocus amplifications can be separated electrophoretically on agarose gels and stained with ethidium bromide, although higher resolution of bands has been achieved with discontinuous polyacrylamide gel electrophoresis (dPAGE) and silver staining (Dinesh et al., 1995). Other merit of RAPDs is the ease with which a large number of loci and individuals can be screened. RAPD makers have been used for identification of a number of fishe species (Partis and Well, 1996), mollusks (Crossland et al., 1993), and analysis of genetic diversity (Wolfus et al., 2002).

There exists an unidentified cichlid 'wesafu', in Epe lagoon, Lagos, Nigeria where it is highly priced (Fashina- Bombata and Megbowon, 2012). This unidentified cichlid grows to $1,500 \mathrm{~g}, 414 \mathrm{~mm}$ in the wild (Fashina-Bombata et al., 2005, 2006, 2007 and 2008). At the present there is paucity of information on the origin of the species of fish.

A number of studies have been conducted on the morphometric and meristic characteristics, age and growth, food and feeding habit, nutritional requirement and amino acid profile of the fish (Fashina-Bombata and Hammed, 2010, Hammed et al., 2010, Fashina-Bombata et al., 2005, 2006 and 2008). These studies showed some unique characteristics in this cichlid. The present study was conducted to assess the genetic differences between population(s) and determine the level of divergence of 'wesafu' from other species of cichlids in Epe lagoon for baseline documentation. 


\section{Location of Sample Collection}

\section{Materials And Methods}

The fish specimens used in this study were obtained from the commercial artisanal catches at Ebut Chief on Epe Lagoon. The Lagoon (Figure 1) lies between longitude $30^{\circ} 3{ }^{1}$ and $4^{\circ} 05^{1} \mathrm{E}$ and between latitudes $6^{\circ} 29^{1}$ and $6^{\circ} 38{ }^{1} \mathrm{~N}$. It is fed by River Oshun. With a surface area of about $225 \mathrm{~km}^{2}$ and a maximum depth of 6 $\mathrm{m}$, the lagoon is located between the Lagos and Lekki lagoons. A considerable area of the lagoon is relatively shallow with a minimum depth of $1 \mathrm{~m}$, and the vegetation surrounding the Lagoon is of the mangrove swampy type. The lagoon opens into the Gulf of Guinea via the Lagos Harbour.

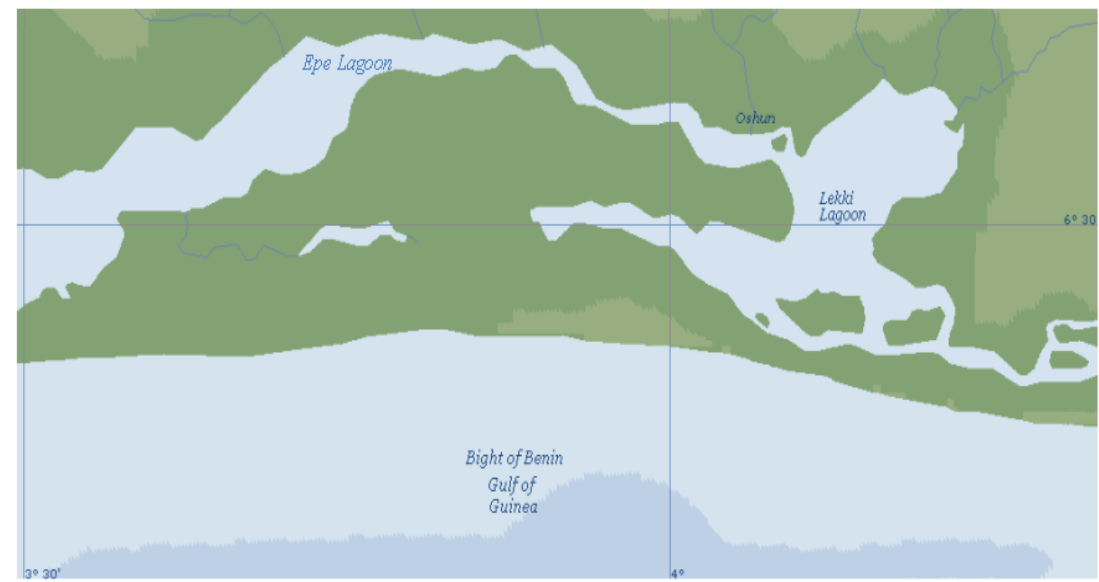

Fig,1: Map showing Epe lagoon, Lagos, Nigeria

\section{Genetic Characterization}

The randomly amplified polymorphic DNA (RAPD) technique includes the amplification, by polymerase chain reaction (PCR), of random segments of genomic DNA using a single short primer of arbitrary sequence (Callejas and Ochando, 1998). The molecular markers in the present work were performed on nuclear genomic DNA as target and the fin tissues sampled were used.

\section{Stock solutions}

Cell lysis buffer, $\mathrm{pH} 8\left(4^{0} \mathrm{C}\right)$

$100 \mathrm{mM}$ Tris.HCL, $\mathrm{pH} 8.0$

$1.21 \mathrm{~g}$

$100 \mathrm{mM} \mathrm{Na}_{2}$.EDTA, $\mathrm{pH} 8.0$

$3.722 \mathrm{~g}$

$500 \mathrm{mM} \mathrm{NaCl}$ (Pure)

$2 \%$ SDS

$\mathrm{H}_{2} \mathrm{O}$ (distilled water) upto

Proteinase K solution $(10 \mathrm{mg} / \mathrm{ml})$

Proteinase K( $10 \mathrm{mg} / \mathrm{ml}$ ) (Sigma)

$\mathrm{H}_{2} \mathrm{O}$ (d.d.w)

$0.01 \mathrm{~g}$

Stored at $-20^{\circ} \mathrm{C}$

\section{RNase A or T solution}

RNaseA or T

$10 \mathrm{Mm}$ Tris base

$0.05 \mathrm{~g}$

$15 \mathrm{~m} \mathrm{Na} \mathrm{Cl}$

$0.04 \mathrm{~g}$

$\mathrm{H}_{2} \mathrm{O}$ (d.d.w) up to

$40 \mathrm{ml}$

RNase was dissolved in $10 \mathrm{ml}$ of Tris- $\mathrm{NaCl}$ buffer, then boiled for $15 \mathrm{~min}$ and cooled slowly to room temperature and distributed in small tubes and kept at $-20^{\circ} \mathrm{C}$ (Sambrook et al., 1989).

\section{Tris.EDTA buffer (1X TE), PH 8}

$10 \mathrm{mM}$ Tris- $\mathrm{HCl}, \mathrm{pH}, 8.0$

$1 \mathrm{mM} \quad \mathrm{Na}_{2}$-EDTA,pH $\quad 8.0$

$\mathrm{H}_{2} \mathrm{O}$ (d.d.w) up to

$0.121 \mathrm{~g}$

$100 \mathrm{ml}$

This solution was adjusted by $\mathrm{pH}$ and filtered and kept at $4^{\circ} \mathrm{C}$

Stock (5x), Tris-Borate EDTA (TBE, pH 8.3)

Tribase 
Boricacid

$0.5 \mathrm{M} \mathrm{Na} \mathrm{Na}_{2}$-EDA, pH 8.3

$\mathrm{H}_{2} \mathrm{O}$ (d.w) up to

\section{$2.75 \mathrm{~g}$}

$2 \mathrm{ml}$

$100 \mathrm{ml}$

This stock was filtered and kept $4^{0} \mathrm{C}$. $1 \mathrm{X}$ from this stock was used to make a gel and $0.5 \mathrm{X}$ to make running buffer.

7.5 M Ammonium acetate (NH4-Ac): for protein precipitation
Ammonium acetate
7.5M (Molecular Wt:77.08)
$11.6 \mathrm{~g}$
$\mathrm{H}_{2} \mathrm{O} \quad$ (d.w) up to
$20 \mathrm{ml}$
Ethidium bromide

This stock solution was prepared by dissolving $0.1 \mathrm{~g}$ of ethidium bromide (EtBr) in 10ml distilled water and mixed well with magnetic stirrer and then transferred to dark bottle and store at room temperature or $4^{\mathrm{O}} \mathrm{C}$.

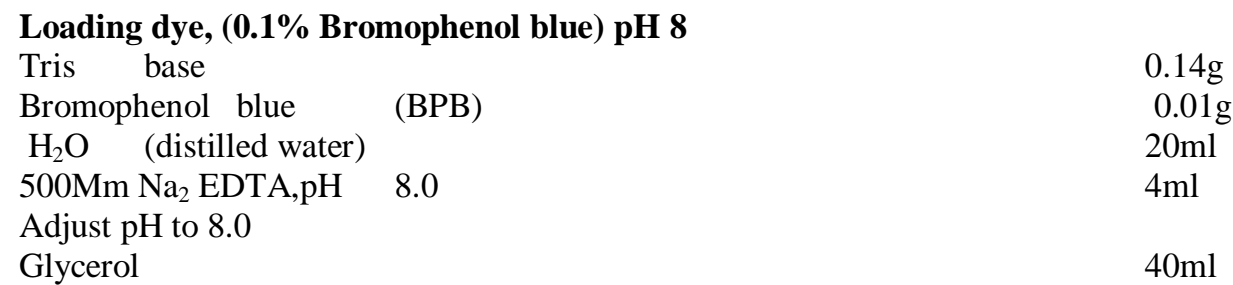

This stock solution was mixed with magnetic stirrer, $\mathrm{pH}$ was adjusted to 8.0 and autoclave must be made then kept at $5^{\circ} \mathrm{C}$ in a dark bottle.

\section{DNA Extraction}

Genomic DNA was extracted according to Hills and Mortitz (1990), as follows:

1. Small pieces of caudal fin tissue (1g) were cut, frozen and ground in a mortear and pestle and $700 \mu \mathrm{l}$ of extraction buffer adde immediately and transferred to new eppendorf tube, then vortexed.

2. $75 \mu \mathrm{l}$ of $20 \%$ SDS was adde, mixed gently and incubated in water bath at $65^{\circ} \mathrm{C}$ for 2 hours.

3. Centrifuged at 10,000rpm for 10 minutes and then transferred to new eppendorf tubes.

4. 500ul Phenol /Chloroform/Isoamy (25:24:1) were added and mixed gently.

5. This was centrifuged at $10,000 \mathrm{rpm}$ at $5^{\circ} \mathrm{C}$ for 10 minutes and transferred the aquaeous phase to new eppendorf tube.

6. Equal volume $(300 \mu \mathrm{l})$ of chloroform / Isoamyl (24:1) was added and mixed gently.

7. This was centrifuged at $10,000 \mathrm{rpm}$ at $5^{\circ} \mathrm{C}$ for 10 minutes and transferred the aqueous phase to new eppendorf tube carefully.

8. $200 \mu \mathrm{l} 5 \mathrm{M}$ potassiumacete was added and mixed gently.

9. $500 \mu \mathrm{l}$ of cold isopropanol was added, mixed gently, incubated at $4{ }^{0} \mathrm{C}$ for 24 hours, then centrifuged at $10,000 \mathrm{rpm}$ for 10 minutes and supernatant was removed carefully.

10. $500 \mu \mathrm{l}$ of $70 \%$ cold ethanol was added for washing and centrifuged at $10,000 \mathrm{rpm}, 5^{\circ} \mathrm{C}$ for 5 minutes.

11. The supernatant is removed and discarded carefully.

12. The pellets were left to air dry for 20 minutes

13. The peplletes were resuspended in $80 \mu \mathrm{l}$ TE buffer, incubated at room temperature for 2 hours and stored at $4^{0} \mathrm{C}$.

14. $5 \mu \mathrm{l}$ of RNase was added for $100 \mu \mathrm{l}$ of sample and incubated at $37^{\circ} \mathrm{C}$ for $3 \quad$ hours.

PCR Mixture

The PCR mixture per genotype consisted of the following:

$\begin{array}{lc}2.5 \mathrm{mM} \text { dNTPs } & 1.3 \mu \mathrm{l} \\ 10 \mathrm{X} \text { reaction buffer }+\mathrm{MgCl} 2 & 1.5 \mu \mathrm{l} \\ 15 \mathrm{ng} \text { primer } & 1.0 \mu \mathrm{l} \\ 25 \mathrm{ng} \text { template DNA } & 1.0 \mu \mathrm{l} \\ 5 \text { units Taq (super thermal) } & 0.2 \mu \mathrm{l} \\ \mathrm{H}_{2} \mathrm{O} \text { (distilled water) } & 7.5 \mu \mathrm{l} \\ \text { Total volume } & \mathbf{1 2 . 5} \boldsymbol{\mu l}\end{array}$

\section{Rapd Pcr Protocol}


Primer OPC-04 (5' CCG CAT CTA C 3'), which are arbitrary primers, were also used to type the isolates as follows. The PCR was performed in a $25 \mu \mathrm{l}$ reaction mixture containing DNA (10-200ng), $200 \mu \mathrm{M}$ of each deoxynucleoside triphosphates (dNTP)(Promega), 2.0mM $\mathrm{MgCl}_{2}, 1 \mathrm{X}$ PCR Buffer, 50pMol of primer, 2 units of Taq DNA polymerase (Promega) and sterile distilled water. PCR conditions consisted of 40 cycles of consecutive denaturation, annealing, and DNA chain extension $\left(1 \mathrm{~min}\right.$ at $94^{\circ} \mathrm{C}, 1 \mathrm{~min}$ at $28^{\circ} \mathrm{C}$, and 2 min at $72^{\circ} \mathrm{C}$ ) in an Eppendorf master Cycler gradient. DNA fragments were separated in a $1 \%$ agarose gels and visualized by ethidium bromide staining. $1 \mathrm{~kb}$ DNA ladders were used as DNA molecular weight standards (Almeida et al, 2004).

\section{Results And Discusion}

The results showed that of the 40 fish isolates typed, 29 isolates (17 of Wesafu and 12 of other cichlids) were positive for RAPD DNA bands after amplification. This gives a typeability of $72.5 \%$ using OPC -04 as the arbitrary primers. The difference observed between 'wesafu' and other cichlids in typeability with OPC-04 was not significant $(\mathrm{P}=0.08)$ (Table 1). Fingerprint analyses revealed 6 distinct RAPD types, 3 for wesafu and 3 for other species of cichlids (Table 2) with molecular sizes of $100-500 \mathrm{bp}$ (Figure 2). The RAPD profile revealed 7 A, B, C, D, E, F and G (table 2)

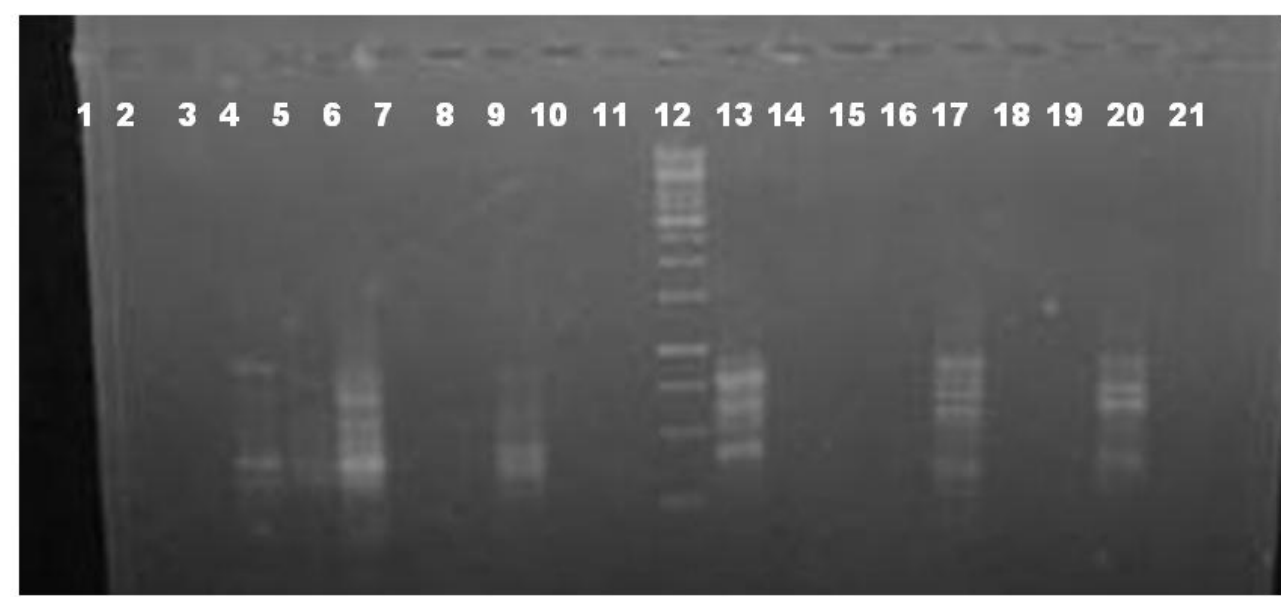

Figure 2: Agarose gel electrophoresis of random polymorphic DNA profiles of species of fish recovered from

Epe Lagoon. Lanes $1-3$ = Tilapia guineensis, lane 4-6=Tilapia mariea, lanes 7-11= Sarotherodon melanotheron.; Lane $12=100$ bp ladder DNA marker; Lanes $13-21=$ Wesafu fish sp.

Table 1: Distribution of the fish species by RAPD typeability

\begin{tabular}{|l|lc|}
\hline Fish isolate & $\begin{array}{l}\text { RAPD typing } \\
\text { Positive } \\
\end{array}$ & $\begin{array}{l}\text { Negative } \\
\mathrm{n}(\%)\end{array}$ \\
\hline Other species of cichlids (tilapia) $(\mathrm{N}=20)$ & $12(60)$ & $8(40)$ \\
'Wesafu' $(\mathrm{n}=20)$ & $17(85)$ & $3(15)$ \\
Total & $29(72.5)$ & $11(27.5)$ \\
& $\mathbf{P = 0 . 0 8}$ & \\
\hline
\end{tabular}

Table 2: The distribution of other cichlids and 'wesafu' fish isolates by RAPD profiles

\begin{tabular}{|c|c|c|c|c|c|c|}
\hline \multirow[t]{2}{*}{ Fish isolate } & \multicolumn{6}{|c|}{ RAPD Profile } \\
\hline & A & B & $\mathrm{C}$ & D & E & F \\
\hline Other species of cichlids & $2(16.7)$ & $7(58.3)^{b}$ & $3(25)$ & $0(0)$ & $0(0)$ & $0(0)$ \\
\hline 'Wesafu' & $0(0)$ & $0(0)$ & $0(0)$ & $3(17.6)$ & $5(29.4)$ & $9(53)^{\mathrm{b}}$ \\
\hline
\end{tabular}

RAPD profile B was elicited by $58.3 \%$ of the Tilapia (other cichlids) isolates, while profile $\mathrm{F}$ was elicited by $53 \%$ of the 'Wesafu' isolates. These most occurring RAPD profiles were not significant $(\mathrm{P}>0.05)$ when compared with other RAPD profiles seen.

\section{Discussion And Conclusion}

Data obtained from molecular analysis (RAPD-PCR) were used to detect the genetic polymorphisms among the tilapiine fished found in Epe lagoon. Genetic similarities among the species of cichlids were detected based on bands polymorphisms which were generated by random primers. RAPD-PCR was successful in 
discriminating between the groups. RAPD molecular technique was utilized to detect the genetic variations among the cichlid populations. This was in agreement with Palti et al. (1997) who reported that DNA fingerprints of mixed DNA samples can be useful in assessing relationship between closely related populations due to the high level genetic differentiation detected. The difference observed between 'wesafu' and other cichlids in typeability with OPC-04 was not significant. This result is similar to that obtained by Liu et al.

(1999) who tested the efficiency of 100 DNA random primers to identify DNA-based genetic polymorphism for constructing a genetic linkage map of channel catfish and blue catfish. Low levels of intraspecific variation in RAPD profiles within the same strain were found. Besides, high level of inter-specific variation was detected between channel catfish and blue catfish. The present study provide evidence that the RAPD markers can be effectively used to discriminate among cichlid populations. This agrees with that obtained by many workers such as Bardakei and Shibinski (1994) who found out that RAPD has been used successfully to detect variations among populations, sub-populations and species. Bielawski and Pumo (1997) also reported that RAPD method is capable of revealing nuclear DNA variations in an extremely conserved species. The development of RAPD marker allows the examination of genome variation without prior knowledge of DNA sequences.

As a result of hybridization among tilapia in the wild, many of these tilapias morphologically similar. RAPD methodology has therefore been applied in studies aiming at species identification whose morphological discrimination remains difficult (Takagi and Taniguchi, 1995; Dinesh et al., 1995; Almeida et al., 2001).

RAPD-PCR proves to be reliable as a typing tool for discriminating 'Wesafu' from other tilapia isolates in Epe Lagoon. 'wesafu' and other tilapia isolates represent fish population from 3 distinct clones in the Epe Lagoon.

\section{References}

[1]. Almeida F.S, Fungaro, M.H.P, and Sodre L.M.K (2001). RAP and isozyme analysis of genetic variability in three allied species of catfish (Siluriformes: Pimelodidae) from the Tibagi river. Journal of Zoology ,Munich, 253:(1), 113-120.

[2]. Almeida, F.S, Fungaro, M.H.P, and Sodre, L.M.K. (2004): RAP and isozyme analysis of genetic variability in three allied species of catfish (Siluriformes: Pimelodidae) from the Tibagi river. Journal of Zoology, Munich, 253(1), 113-120. Ackman R. (1989). Nutritional composition of fats in Seafoods. Progressive Nutrition Sciences 13: 161-241.

[3]. Bardekei F. and Shibinski D.O.F. (1994). Application of RAPD technique in Tilapia fish: species and sub-species identification. Heredity, 73: 117-123.

[4]. Bielawski J.P. and Pumo D.E. (1997). Randomly Amplifies DNA (RAPD) analysis of Atlantic coast stripped bass . Heredity, Oxford, V. 78:32-40.

[5]. Billingto N. (2003). Mitochondrial DNA . E,M.Hallerman (Ed.), Population Genetics: Principles and Application for Fisheries Scientists. American Fisheries Society, Bethesda, Maryland; 59-100.

[6]. Crossland, S., Coates, D., Grahame, J., Mill, P.J., 1993. Use of random amplified polymorphic DNAs (RAPDs) in separating two sibling species of Littorina. Mar. Ecol., Prog. Ser. 96, 301- 305.

[7]. Dinesh, K.R., Chan, W.K., Lim, T.M., Phang, V.P.E., 1995. RAPD markers in fishes: an evaluation of resolution and reproducibility. Asia-Pac. J. Mol. Biol. Biotechnol. 3, 112-118

[8]. Fashina-Bombatta H.A., R.G. Ajepe and A.M. Hemmed and A.A. Jimoh (2005).Characterization of an ecotype cichlid commonly referred to as wesafu, endemic to Epe lagoon, Nigeria. World Aquaculture 36;20-22.

[9]. Fashina-Bombatta H.A, R.G Ajepe and A.M Hemmed (2006). Food and feeding habits of an ecotype cichlid,wesafu from Epe lagoon, Lagos, Nigeria. World Aquaculture , 37; 62-66.

[10]. Hammed A.M, Fashina-Bombata H.A. and Fadaja O.O. (2010). Tissue and blood acids composition of an ecotype cichlid wesafu, Tilapia zilli and Oreochromis niloticus using paper chromatography. Pakistan Journal of Nutrition Pakistani Journal of nutrition 9 (7): 724-727

[11]. Fashina-Bombata H and Megbowon I (2012). Proximate composition and Breeding description of an unidentified cichlid of Epe lagoon, Southwest, Nigeria commonly called 'wesafu'. International Journal of Nutrition and Metabolism Vol. 4(4), 57-63.

[12]. Liu, Z.J., Karsi, A., Dunham, R.A. (1999).Random amplified polymorphic DNA Markers: Usefulness for gene mapping and analysis of genetic variation of catfish. Aquaculture 174, 59-68.

[13]. Liu Z.J, and J.F. Cordes (2004). DNA marker technologies and their applications in aquaculture genetics. Aquaculture 238 (2004) 1 $-37$.

[14]. Palti Y., Parson, J.E, and Thorgaard ,G.H (1997). Assessment of genetic variability among strains of rainbow and cutthroat trout using multilocus DNA fingerprints. Aquaculture, 149: 47-56.

[15]. Partis, L., Wells, R.J. (1996). Identification of fish species using random amplified polymorphic DNA (RAPD).Mol. Cell. Probes $10,435-441$.

[16]. Tagaki, M.and Tanigushi N. (1995). Random Amplified Polymorphic DNA (RAPD) for identification of three species of Anguilla, A. japonica, A. australis and A. bicor Fish science, Tokyo, Vol. 61, No.5,884-885.

[17]. Welsh, J., McClelland, M., 1990. Fingerprinting genomes using PCR with arbitrary primers. Nucleic Acids Res. 18, $7213-7218$.

[18]. Wolfus, G.M., Garcia, D.K., Alcivar-Warren, A., 1997. Application of the microsatellite techniques for analyzing genetic diversity in shrimp breeding programs. Aquaculture 152, 35- 47. 